\title{
What could clinicians do to prevent hospital-based outbreaks of emerging and existing respiratory infectious diseases? Raising awareness is key
}

\author{
Huey-Ming Tzeng ${ }^{1}$, Chang-Yi Yin ${ }^{2}$ \\ 1. College of Nursing, Washington State University, Spokane, WA, USA. 2. Department of History, Chinese Culture \\ University, Taipei, Taiwan.
}

Correspondence: Huey-Ming Tzeng, College of Nursing, Washington State University, P.O. Box 1495, Spokane, WA 99210-1495, USA. Email: tzenghm@gmail.com

Received: December 13, 2012 Accepted: January 15, 2013

URL: http://dx.doi.org/10.5430/cns.v1n1p1

Online Published: January 23, 2013

DOI : $10.5430 /$ cns.v1n1p1

\begin{abstract}
The purpose of this paper is to raise awareness among nurses working in hospitals about occupational respiratory infectious diseases so they may protect themselves and their patients from hospital-acquired respiratory infectious diseases. We found insufficient awareness among nurses about potential hospital-based outbreaks of respiratory infectious diseases in relation to wearing masks to protect themselves and the patients they care for. As for practice implication, a clinical practice norm that nurses are obligated to wear masks during flu season and when feeling under the weather is essential. Placing clinicians' health first is essential since patient safety will follow in the efforts to prevent the next SARS-like tragedy.
\end{abstract}

\section{Key words}

Emerging communicable diseases, SARS virus, Infection control, Infection control practitioners, Hospital

\section{I ntroduction}

During the period from 2003 to 2009, we used academic and popular literature to advocate for nurses, primarily by discussing the professional obligation issues that nurses and other clinicians encounter and the safety concerns in the clinical practice environment related to emerging and existing respiratory infectious diseases (e.g., severe acute respiratory syndrome [SARS], H5N1 avian flu, and tuberculosis). Our focus was the epidemics in Taiwan. Issues we addressed included lack of infection control measures for clinicians during the 2003 SARS outbreak (e.g., N95 masks and gowns) and clinicians' unwillingness to care for SARS-infected patients before knowing the pathogen, the transmission mechanism between humans, and treatment options. Our primary motivator was to help the public understand newly emerging infectious diseases during and after the SARS and H5N1 avian flu pandemics. Together, we published a total of 13 academic and 2 popular literature articles, including 6 data-based, peer-reviewed journal articles (see Table 1).

We believed that publishing findings and opinions at the early stage of the SARS outbreak was essential to make an impact on the governmental and institutional policies related to infection control. Our work demonstrated clinicians' strong desire for transparent communication from both hospital and government officials and expressed clinicians' desperate needs for 
sufficient infection control measures. Our work may have directly or indirectly restored the image of nurses, which was damaged during the SARS outbreak in Taiwan. However, we do not have measureable evidence to illustrate the impact of our work on policy changes.

Table 1. List of the articles related to the outbreaks of SARS in 2003 and H5N1 avian flu in 2006 as well as respiratory infectious diseases published by the authors: 2003-2009.

\begin{tabular}{|c|c|c|c|c|c|}
\hline Year & Language & Article type & $\begin{array}{l}\text { Academic vs. } \\
\text { popular } \\
\text { literature }\end{array}$ & $\begin{array}{l}\text { Focus } \\
\text { area }\end{array}$ & Title (citation) \\
\hline 2003 & Chinese & $\begin{array}{l}\text { Databased, } \\
\text { peer-reviewed, historical, } \\
\text { journal article }\end{array}$ & Academic & SARS & $\begin{array}{l}\text { Tale and reality about the SARS epidemic: The needs to } \\
\text { build the psychology of infectious diseases }{ }^{[35]} \text {. }\end{array}$ \\
\hline 2003 & English & $\begin{array}{l}\text { Databased, } \\
\text { peer-reviewed, journal } \\
\text { article }\end{array}$ & Academic & SARS & $\begin{array}{l}\text { SARS infection control in Taiwan: Investigation of nurses' } \\
\text { professional obligation }{ }^{[17]} \text {. } \\
\text { Reprint included in the book of SARS in Taiwan: One year } \\
\text { after the outbreak, published by the Center for Disease } \\
\text { Control, Department of Health, Taiwan, R.O.C }{ }^{[22]} \text {. }\end{array}$ \\
\hline 2003 & English & $\begin{array}{l}\text { Review, peer-reviewed, } \\
\text { journal article }\end{array}$ & Academic & SARS & $\begin{array}{l}\text { Fighting the SARS epidemic in Taiwan: A nursing } \\
\text { perspective }^{[18]} \text {. } \\
\text { Reprint included in the book of SARS in Taiwan: One year } \\
\text { after the outbreak }{ }^{[19]} \text {. }\end{array}$ \\
\hline 2004 & English & $\begin{array}{l}\text { Databased, } \\
\text { peer-reviewed, journal } \\
\text { article }\end{array}$ & Academic & SARS & $\begin{array}{l}\text { Nurses' professional obligation and their attitudes towards } \\
\text { SARS infection control measures in Taiwan: during and } \\
\text { after the } 2003 \text { SARS epidemic }{ }^{[20]} \text {. }\end{array}$ \\
\hline 2004 & English & $\begin{array}{l}\text { Review, peer-reviewed, } \\
\text { journal article }\end{array}$ & Academic & SARS & $\begin{array}{l}\text { Roles of nurse aides and family members in acute patient } \\
\text { care in Taiwan }{ }^{[21]} \text {. }\end{array}$ \\
\hline 2005 & English & $\begin{array}{l}\text { Databased article/book } \\
\text { chapter }\end{array}$ & Academic & SARS & $\begin{array}{l}\text { The case of SARS infection control in Taiwan: An } \\
\text { investigation on the professional obligation of health care } \\
\text { providers }{ }^{[25]} \text {. }\end{array}$ \\
\hline 2005 & Chinese & $\begin{array}{l}\text { Newspaper } \\
\text { article/professional } \\
\text { comment }\end{array}$ & $\begin{array}{l}\text { Popular } \\
\text { literature }\end{array}$ & $\begin{array}{l}\text { SARS, } \\
\text { H5N1 } \\
\text { avian flu }\end{array}$ & $\begin{array}{l}\text { Nurses have the right to feel fearful toward newly } \\
\text { emerging infectious diseases }{ }^{[23]} \text {. }\end{array}$ \\
\hline 2005 & English & $\begin{array}{l}\text { Review, peer-reviewed, } \\
\text { journal article }\end{array}$ & Academic & $\begin{array}{l}\text { Occupati } \\
\text { onal } \\
\text { tuberculo } \\
\text { sis }\end{array}$ & $\begin{array}{l}\text { Promoting a safer practice environment as related to } \\
\text { occupational tuberculosis: a nursing care quality issue to } \\
\text { Taiwanese nursing environment }{ }^{[24]} \text {. }\end{array}$ \\
\hline 2006 & Chinese & $\begin{array}{l}\text { Review, peer-reviewed, } \\
\text { journal article }\end{array}$ & Academic & $\begin{array}{l}\text { SARS, } \\
\text { emerging } \\
\text { infectious } \\
\text { diseases }\end{array}$ & $\begin{array}{l}\text { The impact of newly emerging infectious diseases on } \\
\text { human beings and successive changes }{ }^{[16]} \text {. }\end{array}$ \\
\hline 2006 & English & $\begin{array}{l}\text { Review, peer-reviewed, } \\
\text { journal article }\end{array}$ & Academic & SARS & $\begin{array}{l}\text { Learning to respect a patient's spiritual needs concerning } \\
\text { an unknown infectious disease }{ }^{[26]} \text {. }\end{array}$ \\
\hline 2006 & English & $\begin{array}{l}\text { Comment, } \\
\text { peer-reviewed, journal } \\
\text { article }\end{array}$ & Academic & $\begin{array}{l}\text { H5N1 } \\
\text { avian flu }\end{array}$ & $\begin{array}{l}\text { Is H5N1 like a ghost-flu that can cause a pandemic in } \\
\text { humans? }{ }^{[27]}\end{array}$ \\
\hline 2006 & Chinese & $\begin{array}{l}\text { Newspaper article/ } \\
\text { professional comment }\end{array}$ & $\begin{array}{l}\text { Popular } \\
\text { literature }\end{array}$ & $\begin{array}{l}\text { SARS, } \\
\text { infectious } \\
\text { diseases }\end{array}$ & The responsibility of patients with infectious diseases ${ }^{[28]}$. \\
\hline 2006 & English & $\begin{array}{l}\text { Databased, } \\
\text { peer-reviewed, journal } \\
\text { article }\end{array}$ & Academic & $\begin{array}{l}\text { H5N1 } \\
\text { avian flu }\end{array}$ & $\begin{array}{l}\text { Nurses' fears and professional obligations concerning } \\
\text { possible human-to-human avian influenza }{ }^{[29]} \text {. }\end{array}$ \\
\hline 2008 & English & $\begin{array}{l}\text { Review article/book } \\
\text { chapter }\end{array}$ & Academic & $\begin{array}{l}\text { SARS, } \\
\text { H5N1 } \\
\text { avian flu }\end{array}$ & $\begin{array}{l}\text { Globalisation and pandemic: Fighting against the spread of } \\
\text { infectious diseases }{ }^{[30]} \text {. }\end{array}$ \\
\hline 2009 & Chinese & $\begin{array}{l}\text { Databased, } \\
\text { peer-reviewed, historical, } \\
\text { journal article }\end{array}$ & Academic & SARS & $\begin{array}{l}\text { Taiwan’s SARS experience (2003-2008), The public } \\
\text { health catastrophe and politics }{ }^{[36]} \text {. }\end{array}$ \\
\hline
\end{tabular}


Aiming to prevent the spread of the next SARS-like emerging infectious disease, Aghaizu and associates ${ }^{[1]}$ emphasized that "hospitals are often the epicentres of newly circulating infections. Healthcare workers...are at high risk of acquiring infectious diseases and may be among the first to contract emerging infections...”. We ask: are our frontline nurses aware of their high risk of contracting emerging respiratory infectious diseases, and are they protecting themselves from occupational infections?

\section{Purpose of this paper}

This discussion article is intended to raise awareness among frontline nurses working in hospital settings about emerging and existing respiratory infectious diseases so they may protect themselves and their patients from hospital-acquired respiratory infectious diseases. The article includes a brief overview of the recent outbreaks of respiratory infectious diseases and the 2003 SARS pandemic. We discussed clinicians' emotional distress related to pandemic influenza, their perception of risk factors for acquiring infectious disease, and barriers to implementing infection control measures and using personal protective equipment. Practical implications are discussed. Wearing personal protective equipment, specifically masks, is the focus of this paper.

\section{Background and brief literature review}

\subsection{Recent outbreaks of respiratory infectious diseases}

The 2003 SARS pandemic ${ }^{[5]}$, the 2003-2007 highly pathogenic avian influenza A (H5N1) virus pandemic ${ }^{[6]}$, the 2009 H1N1 swine flu pandemic ${ }^{[7]}$, the $2012 \mathrm{H} 3 \mathrm{~N} 2 \mathrm{v}$ swine flu epidemic in the United States ${ }^{[8,32]}$, and the 2012 pertussis epidemic in the state of Washington ${ }^{[9]}$ represent several recent outbreaks of infectious diseases. Some of them (i.e., SARS and H5N1 pandemics) appeared without warning and have had significant global impact on human health, including in developed countries (e.g., United States, Canada). SARS was a newly emerging infectious disease which hit hard worldwide in early 2003. SARS can be easily transmitted from human to human. H5N1 avian flu is not readily transmitted between humans; however, such transmission does occur occasionally ${ }^{[4,27,34]}$.

\subsection{SARS as a global threat}

When SARS surfaced, it caught us off guard. The outbreak started in November 2002. Between November 1, 2002, and July 31, 2003, SARS spread to 29 countries in North America, South America, Europe, and Asia. It was identified as a global threat to human health, with 8096 cumulative probable cases and 774 deaths ${ }^{[5,33]}$.SARS is a viral respiratory illness caused by a coronavirus (CoV); the cause was identified and reported in Asia in February $2003{ }^{[5]}$. SARS-CoV is transmitted primarily through droplets and close personal contact, when droplets containing SARS-CoV are propelled a short distance via the air (e.g., by talking, coughing, or sneezing) and deposited in the eyes, nose or mouth of a susceptible person $^{[3]}$.

In the United States, 27 cases were classified as probable SARS, but no deaths occurred ${ }^{[33]}$. The United States had only eight laboratory-confirmed cases of SARS-CoV disease and no significant local spread ${ }^{[3]}$. Many of the factors underlying outbreaks in other countries (e.g., Hong Kong, Singapore, Taiwan, and Canada) exist in the United States and it could be only by chance that a SARS outbreak did not occur in the United States. In areas characterized by extensive SARS outbreaks, hospitals accounted for a large proportion (often>50\%) of probable SARS cases. Early SARS-CoV transmission occurred predominantly among healthcare workers, patients, and visitors in hospital settings. In many instances, they also propagated the outbreaks within hospitals and into the community. Rapid isolation of possible cases and strict adherence to infection control precautions have consistently been an effective part of SARS control strategies ${ }^{[3]}$. 


\subsection{Clinicians' emotional distress related to pandemic influenza}

During the SARS and H5N1 avian flu pandemics, fear and panic emerged among clinicians and nonclinicians. These effects were often due to the unknown cause, possible fatal outcome, often-delayed detection and diagnosis, as well as unclear treatment and prevention mechanisms ${ }^{[15,17,18,26,29]}$. A study conducted by Maunder and associates ${ }^{[14]}$ from October 23, 2004, through September 30, 2005, in Ontario, Canada, addressed the long-term psychological and occupational effects of providing hospital healthcare during the SARS outbreak at 9 Toronto hospitals that treated SARS patients and 4 Hamilton hospitals that did not. Of the total 769 healthcare worker participants, $73.5 \%$ were staff nurses, nurse managers or educators, or infection control nurses. Toronto healthcare workers had significantly higher levels of burnout, psychological distress, and posttraumatic stress than the Hamilton healthcare workers. Toronto healthcare workers were also more likely to have reduced patient contact and work hours and to report behavioral consequences of stress. These differences were explained by Toronto healthcare workers' perceived adequacy of training, protection, and moral support, as well as their adaptive coping style. Maunder and associates ${ }^{[14]}$ also found a trend toward lower burnout in the intensive care unit workers and less general psychological distress in the emergency department workers among Toronto healthcare workers. They suggested that these trends arose from the resilience of these healthcare workers, who were accustomed to working in high-intensity and high-risk settings (e.g., intensive care units and emergency departments). Overall, regardless of their degree of contact with SARS patients, Toronto healthcare workers had generally higher distress levels than the Hamilton workers. This finding suggested that whether a hospital treated SARS patients during the outbreak had a negative effect on workers' distress levels.

A qualitative study conducted in the United Kingdom by Ives and associates ${ }^{[12]}$ found that healthcare workers tend to feel obligated to work during an influenza pandemic. Barriers to their willingness to work during an influenza pandemic are (1) prioritizing the well-being of their family members, (2) lacking trust in their government's health department, (3) lacking information about the risks during the crisis, (4) fearing litigation during care delivery, and (5) lacking support from employers to address their needs ${ }^{[12]}$. A survey study conducted by Damery and associates ${ }^{[10]}$ similarly found that healthcare workers feel that they have a duty to work during pandemics despite personal risk. However, their sense of the duty may be compromised by their sense of duty to their families and their perception of a lack of reciprocity from employers.

\subsection{Risk factors and barriers}

The qualitative study conducted in 2010 in 4 European countries by Aghaizu and associates ${ }^{[1]}$ found that healthcare workers perceived risk factors for acquiring infectious diseases like SARS at work in hospital settings to be (1) exposure to patients with undiagnosed infections, (2) breakdown in infection control procedures, (3) lack of immunity, and (4) symptomatic colleagues. Aghaizu and associates ${ }^{[1]}$ also identified known measured barriers for the timely recognition of outbreaks of SARS-like infectious diseases within hospital settings. These barriers were (1) lack of knowledge among clinicians, (2) lack of employee absence-reporting mechanism, (3) differences in absence monitoring among hospital-affiliated workers and non-hospital-affiliated workers (e.g., self-employed doctors and agency nurses), (4) limited personal protective equipment and patient isolation facility due to financial restraints, and (5) lack of personnel and financial resources in hospitals' occupational health departments.

Healthcare workers emphasized a desire for timelier recognition of outbreaks of emerging infections and for structural improvements of their working hospitals (e.g., standardized employee absence and infectious disease symptom reporting systems) ${ }^{[1]}$. They were concerned that a lack of monitoring and guidelines for infectious healthcare workers posed a great risk to colleagues and patients. However, healthcare workers revealed that they have the tendency to come to work even when they don't feel well and their employers tend to expect them to come in if they are slightly under the weather. They felt that employers did not seem to take a positive interest in their health. Staffing demands and loss of income were noted as pressures for healthcare workers to attend work when unwell. However, issues related to legislation, privacy, and confidentiality were previously identified as barriers towards monitoring staff absence and the routine disclosure of symptoms ${ }^{[1]}$. In short, there are measured barriers to preventing disease spread. Healthcare workers have a sense of what 
the barriers are, but their knowledge is incomplete. Relying on perceptions rather than knowledge places both healthcare workers and their patients at risk and could fuel disease spread during an outbreak.

\subsection{Use of personal protective equipment}

Do frontline nurses routinely use personal protective equipment (e.g., masks, gloves) ${ }^{[3]}$ in encounters with patients that have respiratory illness? Aghaizu and associates ${ }^{[1]}$ found that the healthcare workers in emergency departments in European countries often do not put on personal protective equipment (e.g., masks and gloves) when they encounter patients with respiratory illness symptoms. However, if a possible diagnosis of infectious illness is made, they could get afraid that they may have been infected and then they put on a mask and gloves ${ }^{[1]}$. Our observations and conversations with frontline nurses have a similar conclusion; it seems that the majority of the nurses working in US hospital settings or clinics do not routinely use personal protective equipment around patients with respiratory illness. Recent conversations with a group of Registered Nurse (RN) students follow.

In 2012, one of the authors participated in a seminar to a group of RN to baccalaureate of science in nursing students in the northwest region of the United States. Part of the discussion was related to wearing masks to prevent hospital-based respiratory infectious disease outbreaks. The majority of the students had never encountered patients with a recent emerging infectious disease such as SARS or H5N1, H1N1, or H3N2v swine flu. However, they were aware that Centers for Disease Control and Prevention had issued guidelines on infection control, such as those for preventing SARS dissemination.

One student expressed that in her practice, if her patients have symptoms of respiratory infection (e.g., coughs, sneezing), she may offer masks to them and their family members. Unless she is entering an isolation room though, she does not routinely wear a mask when encountering patients with respiratory illness symptoms. A few students stated that they do not wear masks because they feel healthy, have a good immune system, and never get sick. None of these RN students said that they would wear a mask if they were on duty with flu or flu-like symptoms.

Despite being aware that wearing masks can decrease droplet transmission, they would not put on masks to protect either themselves or their patients. A student stated that catching seasonal flus may strengthen her immune system and that is why she does not see the need to wear a mask when dealing with patients with respiratory illness. Another student claimed that employers require nurses to have a certain vaccinations including a seasonal flu shot. Therefore, she was not concerned about catching respiratory infections at work (e.g., seasonal flus, pertussis, and tuberculosis) or becoming a carrier to disseminate these respiratory infectious diseases to other healthcare workers, patients, and visitors. The issue of over-relying on vaccines for protection without taking into account of, such as, vaccine efficacy and waning immunity for Bordetella pertussis ${ }^{[11]}$ was not discussed during the seminar.

A student expressed that she was not aware that people in Asian countries continued to wear masks even after the SARS outbreak ended. She learned that it is a cultural norm in some countries for people to wear masks during the flu season, when feeling under the weather, or to avoid breathing in polluted air. This student expressed that previously when she saw someone with a mask, she wondered what the person had that was contagious. She never suspected that they might be wearing a mask because it is a social norm.

At the end of the discussions, a student commented that it sounds like a highly pathogenic emerging infectious disease outbreak is an accident waiting to happen. She emphasized that one of these days we will most likely experience a pandemic or infectious disease outbreak of some sort. Hospitals in our area could be hit very hard. Making sure proper infection control procedures are in place now is important to ensure patient safety and our own health. 


\section{Conclusions}

The reviewed literature ${ }^{\left[e^{-g, y}, 1\right]}$ and discussions in the previous section illustrate the insufficient awareness among frontline nurses about potential hospital-based outbreaks of emerging and existing respiratory infectious diseases in relation to wearing masks to protect themselves and the patients they care for. Despite our nurses that attended the seminar described in the previous section knowing that wearing masks could decrease droplet transmission (learned via education or on-job training), they did not routinely put on masks when encountering patients with respiratory illness symptoms or when they themselves had contagious respiratory illness (e.g., flu-like symptoms). These statements may not be generalizable to all frontline nurses and need to be verified in broader evidence through observation or survey studies on frontline nurses.

In professional training and practice settings, the 6Rs process of putting professional knowledge learned through education or training into practice includes 6 steps: ${ }^{[31]}$ (1) Retaining prior knowledge, (2) Recognizing previously studied scenarios in practical settings (e.g., an outbreak of occupational tuberculosis in inpatient care settings), (3) Retaining know-how (e.g., knowing the needed infection control precautions based on the epidemic situation and how to apply them), (4) Reinforcing knowledge via on-the-job training and regulations (e.g., establishing hospital policies related to infection control precautions), (5) Realizing prior knowledge by doing (“To-Do") (e.g., being able to identify patients with a possible respiratory infectious disease and acting accordingly as a form of translating research-based knowledge to practice, also called evidence-based practice), and (6) observing Results (e.g., decreased occurrences of occupational tuberculosis and chances of a hospital-based respiratory infectious disease outbreak) ${ }^{[31]}$.

We assume that with timely and proper training, agreement between nurses' perceptions and their prior knowledge related to respiratory infectious diseases gained via infection control training could be established through clinical and observational experience. A disagreement could be due to a lack of awareness of the necessity of using infection control precautions (e.g., wearing masks) and their usefulness in avoiding respiratory illness and preventing transmission to others ${ }^{[31]}$.

\section{Practical implications}

A clinical practice norm in which clinicians, including nurses and other healthcare workers, are obligated to wear masks during flu season and when feeling under the weather is essential to effectively prevent hospital-based outbreaks of emerging and existing respiratory infectious diseases. This suggested approach is made within the global health context. It is applicable to developed, developing, and least developed countries. Before a new clinical practice norm is established, clinicians may feel that wearing face masks could be perceived by patients and their family members as having a potential physical barrier for effective communication. We believe that the advantage of wearing face masks during flu season will outweigh this potential disadvantage. Both clinician and patient/family education on the advantages of wearing face masks during flu season and when feeling under the weather is essential to effectively prevent hospital-based outbreaks of respiratory infectious diseases.

The costs of implementing this suggested policy to protect clinicians are affordable (for example, we may purchase 50 pieces of face masks online for about $\$ 8$ to 15 USD). Communicating with the finance department the advantage to increase the stock of face masks is essential. Placing clinicians' health first is essential since patient safety will follow in the efforts to prevent the next SARS-like tragedy in hospital settings.

As part of the staff support from hospital employers, transparency regarding outbreaks of infectious diseases within and outside each hospital is important for frontline nurses to react quickly and appropriately. With timely and proper infection control training and practice, agreement between nurses' perceptions and their prior knowledge related to respiratory infectious diseases may be established. Again, it is important that hospitals need to go beyond promoting a safe practice 
environment associated with occupational tuberculosis ${ }^{[24]}$ and extend occupational health efforts to emerging and other existing respiratory infectious diseases.

Based on our observation, aside from when they enter isolation rooms, frontline nurses do not seem to be accustomed to using personal protection (e.g., wearing masks, adhering to good hand hygiene including wearing gloves) when dealing with patients with respiratory illness symptoms or when they themselves have respiratory illness symptoms (e.g., flu-like symptoms). This practice pattern could fuel a crisis when the next SARS-like pandemic attacks. Our frontline nurses, especially those working in emergency departments and clinics, are at high risk and are susceptible to catching infectious disease. To protect themselves and promote patient safety by preventing hospital-acquired respiratory infectious diseases, it is essential to raise awareness about personal protective equipment and infection control measures in a timely manner among licensed and unlicensed nursing staff via on-job training and among future nurses (e.g., student nurses) via formal nursing school education. Repeated training and reminders are warranted to ensure compliance and change the practice pattern among nurses.

Hospitals should consider employing infection control nurses ${ }^{[2,13]}$ for early detection and monitoring of potential outbreaks of emerging and existing infectious diseases in emergency departments, clinics, and inpatient care settings. Solely relying on surveillance reports prepared by a regional health department could delay healthcare workers being alerted to a potential outbreak of respiratory infectious diseases. Infection control nurses certified by the Certification Board of Infection Control and Epidemiology, Inc. ${ }^{[2]}$ are qualified to help prevent patient infections in hospitals and clinics, as well as to instruct other nurses and healthcare workers on proper infection prevention procedures ${ }^{[13]}$. Each hospital's emergency room should have at least one nurse with training on detecting early signs of an outbreak.

As suggested by Maunder and associates ${ }^{[14]}$, along with careful planning and preparation before the next outbreak comes, effective staff support could be key to bolstering the resilience of healthcare workers facing future outbreaks. Effective staff support includes, but is not limited to, psychological support in the context of trusted professional and institutional relationships, responsible communication with staff, opportunities for facilitated reflection on normal emotional responses to extraordinary stress, and opportunities for healthcare workers to contribute to decision-making in the workplace ${ }^{[14]}$. Monitoring among healthcare workers in hospital settings may be a feasible means of surveillance for possible outbreaks of occupational respiratory infectious diseases, especially in emergency departments. To overcome the barriers associated with monitoring staff absence and the routine disclosure of symptoms, issues related to legislation, privacy, and confidentiality need to be addressed at both the regional- and governmental-level health departments ${ }^{[1]}$.

\section{Future research}

Future research should investigate how many hospitals within a specific country and across countries are currently taking the suggested approaches discussed above. Researchers may survey hospitals the strategies they have adopted to prevent hospital-based outbreaks of emerging and existing respiratory infectious diseases. It is also essential to understand the impact after implementing the relevant strategies to prevent hospital-based outbreaks of respiratory infectious diseases on clinicians' occupational health.

\section{Conflict of I nterest}

The authors declare no conflict of interest.

\section{References}

[1] Aghaizu A, Elam G, Ncube F, Thomson G, Szilágyi E, Eckmanns T, Poulakou G, Catchpole M. Preventing the next 'SARS'-European healthcare workers' attitudes towards monitoring their health for the surveillance of newly emerging 
infections: qualitative study. BMC Public Health. 2011; 11: 541. Available from:

http://www.ncbi.nlm.nih.gov/pmc/articles/PMC3160373/pdf/1471-2458-11-541.pdf. Accessed September 12, 2012.

PMid:21740552 http://dx.doi.org/10.1186/1471-2458-11-541

[2] Certification Board of Infection Control and Epidemiology, Inc. Certification in Infection Prevention and Control: Candidate Handbook. Certification Board of Infection Control and Epidemiology, Inc. and Applied Measurement Professionals, Inc., Milwaukee, WI. 2012. Available from: http://www.cbic.org/UserFiles/file/2012CandidateHandbook_v1.pdf. Accessed September 9, 2012.

[3] Centers for Disease Control and Prevention. Severe Acute Respiratory Syndrome: Core Document. 2004. Available from: http://www.cdc.gov/sars/guidance/core/downloads/core-full.pdf. Accessed September 15, 2012.

[4] Centers for Disease Control and Prevention. Avian Influenza: Current H5N1 Situation. 2008. Available from: http://www.cdc.gov/flu/avian/outbreaks/current.htm. Accessed September 7, 2012.

[5] Centers for Disease Control and Prevention. Severe Acute Respiratory Syndrome (SARS). 2012. Available from: http://www.cdc.gov/sars/index.html. Accessed September 6, 2012.

[6] Centers for Disease Control and Prevention. Human Infection with Avian Influenza A (H5N1) Virus: Advice for Travelers. 2012. Available from: http://wwwnc.cdc.gov/travel/page/human-infection-avian-flu-h5n1-advice-for-travelers-current-situation.htm. Accessed September 7, 2012.

[7] Centers for Disease Control and Prevention. 2009 H1N1 Flu (“Swine Flu”) and You. 2012. Available from: http://www.cdc.gov/h1n1flu/qa.htm. Accessed September 6, 2012.

[8] Centers for Disease Control and Prevention. Influenza A (H3N2) Variant Virus Outbreaks. Available from: http://www.cdc.gov/flu/swineflu/h3n2v-outbreak.htm. 2012. Accessed September 6, 2012.

[9] Centers for Disease Control and Prevention. Pertussis Epidemic_-Washington, 2012. Morbidity and Mortality Weekly Report. 2012; 61(28): 517-522. Available from: http://www.cdc.gov/mmwr/preview/mmwrhtml/mm6128a1.htm?s_cid=mm6128a1_w. Accessed September 6, 2012. PMid:22810264

[10] Damery S, Draper H, Wilson S, Greenfield S, Ives J, Parry J, Petts J, Sorell T. Healthcare workers' perceptions of the duty to work during an influenza pandemic. Journal of Medical Ethics. 2010; 36(1): 12-18. PMid:20026687 http://dx.doi.org/10.1136/jme.2009.032821

[11] Higgs R, Higgins SC, Ross PJ, Mills KH. Immunity to the respiratory pathogen Bordetella pertussis. Mucosal Immunology.2012; 5(5): 485-500. PMid:22718262 http://dx.doi.org/10.1038/mi.2012.54

[12] Ives J, Greenfield S, Parry JM, Draper H, Gratus C, Petts JI, Sorell T,Wilson S. Healthcare workers' attitudes to working during pandemic influenza: a qualitative study. BMC Public Health.2009; 9: 56. Available from: http://www.ncbi.nlm.nih.gov/pmc/articles/PMC2654560/pdf/1471-2458-9-56.pdf. Accessed September 11, 2012. PMid:19216738 http://dx.doi.org/10.1186/1471-2458-9-56

[13] Johnson \& Johnson Services, Inc. Infection control nurse [internet]. 2012. Available from: http://www.discovernursing.com/specialty/infection-control-nurse. Accessed September 9, 2012.

[14] Maunder RG, Lancee WJ, Balderson KE, Bennett JP, Borgundvaag B, Evans S, Fernandes CM, Goldbloom DS, Gupta M, Hunter JJ, McGillis Hall L, Nagle LM, Pain C, Peczeniuk SS, Raymond G, Read N, Rourke SB, Steinberg RJ, Stewart TE, VanDeVelde-Coke S, Veldhorst GG, Wasylenki DA. Long-term psychological and occupational effects of providing hospital healthcare during SARS outbreak. Emerging Infectious Diseases. 2006; 12(12); 1924-1932. PMid:17326946 http://dx.doi.org/10.3201/eid1212.060584

[15] Person B, Sy F, Holton K, Govert B, Liang A, National Center for Infectious Diseases/SARS Community Outreach Team. Fear and stigma: the epidemic within the SARS outbreak. Emerging Infectious Diseases. 2004; 10(2): 358-363. PMid:15030713 http://dx.doi.org/10.3201/eid1002.030750

[16] Tsai YY, Tzeng HM, Yin CY. The impact of newly emerging infectious diseases on human beings and successive changes. Hospital (Taiwan). 2006; 39(1): 8-20 (in Chinese).

[17] Tzeng HM. SARS infection control in Taiwan: Investigation of nurses’ professional obligation. Outcomes Management, 2003; 7(4): 186-193.

[18] Tzeng HM. Fighting the SARS epidemic in Taiwan: A nursing perspective. Journal of Nursing Administration. 2003; 33(11), 565-567. PMid:14608214 http://dx.doi.org/10.1097/00005110-200311000-00005

[19] Tzeng HM. Fighting against the SARS epidemic in Taiwan: A nursing perspective. In SARS in Taiwan: One year after the outbreak (Center for Disease Control, Department of Health, Taiwan, R.O.C. ed.). Center for Disease Control, Department of Health, Taiwan, R.O.C. 2004. (reprint from the Journal of Nursing Administration. 2003; 33(11): 565-567). 
[20] Tzeng HM. Nurses' professional obligation and their attitudes towards SARS infection control measures in Taiwan: during and after the 2003 SARS epidemic. Nursing Ethics. 2004; 11(3): 277-289. PMid:15176641 http://dx.doi.org/10.1191/096733004ne695oa

[21] Tzeng HM. Roles of nurse aides and family members in acute patient care in Taiwan. Journal of Nursing Care Quality. 2004; 19(2): 169-175. PMid:15077835 http://dx.doi.org/10.1097/00001786-200404000-00015

[22] Tzeng HM. SARS infection control in Taiwan: Investigation of nurses’ professional obligation. In SARS in Taiwan: One year after the outbreak (Center for Disease Control, Department of Health, Taiwan, R.O.C. ed.), Center for Disease Control, Department of Health, Taiwan, R.O.C. (reprint from Outcomes Management. 2004; 7(4): 186-193).

[23] Tzeng HM. Nurses have the right to feel fearful toward newly emerging infectious diseases. Min Sheng Daily (Taipei, Taiwan). 2005 November: A12 (in Chinese).

[24] Tzeng HM. Promoting a safer practice environment as related to occupational tuberculosis: a nursing care quality issue to Taiwanese nursing environment. Journal of Nursing Care Quality. 2005; 20(4): 356-363. PMid:16177588 http://dx.doi.org/10.1097/00001786-200510000-00012

[25] Tzeng HM, Chang CS. The case of SARS infection control in Taiwan: An investigation on the professional obligation of health care providers. In Progress in SARS Research (Griffen AS ed.). New York: Nova Science Publishers; 2005: 119-140.

[26] Tzeng HM, Yin CY. Learning to respect a patient's spiritual needs concerning an unknown infectious disease. Nursing Ethics. 2006; 13(1): 17-28. PMid:16425901 http://dx.doi.org/10.1191/0969733006ne847oa

[27] Tzeng HM, Yin CY. Is H5N1 like a ghost-flu that can cause a pandemic in humans? Nursing Ethics. 2006; 13(3): $219-221$. PMid:16711181 http://dx.doi.org/10.1191/0969733006ne870xx

[28] Tzeng HM, Yin CY. The responsibility of patients with infectious diseases. Min Sheng Daily (Taipei, Taiwan). 2006 June: B9 (in Chinese).

[29] Tzeng HM, Yin CY. Nurses' fears and professional obligations concerning possible human-to-human avian influenza. Nursing Ethics. 2006; 13(5): 455-470. PMid:16961111 http://dx.doi.org/10.1191/0969733006nej893oa

[30] Tzeng HM, Yin CY. Globalisation and pandemic: Fighting against the spread of infectious diseases. In The Globalization of Nursing (V. Tschudin V \& Davis A eds.), Radcliffe Medical, London, UK. 2008:189-197.

[31] Tzeng HM, Yin CY. Frequently observed risk factors for fall-related injuries and effective preventive interventions for adult inpatients in acute hospital settings: a multihospital survey of nurses’ perceptions. Journal of Nursing Care Quality. 2013; 28(2). In press.

[32] World Health Organization. Increase in A H3N2v detections in the United States. 2012. Available from: http://www.euro.who.int/en/what-we-do/health-topics/communicable-diseases/influenza/news/news/2012/8/increase-in-a-h3n2vdetections-in-the-united-states. Accessed September 6, 2012.

[33] World Health Organization. Summary of probable SARS cases with onset of illness from 1 November 2002 to 31 July 2003.2012. Available from: http://www.who.int/csr/sars/country/table2004_04_21/en/index.html. Accessed September 6, 2012.

[34] World Health Organization. FAQs: H5N1 influenza-Q1: What is H5N1? 2012. Available from: http://www.who.int/influenza/human_animal_interface/avian_influenza/h5n1_research/faqs/en/. Accessed September 6, 2012.

[35] Yin CY. Tale and reality about the SARS epidemic: The needs to build the psychology of infectious diseases. History Journal Monthly (Taipei, Taiwan). 2003; 186: 30-38 (in Chinese).

[36] Yin CY, Tzeng HM. Taiwan's SARS experience (2003-2008). The public health catastrophe and politics. History Journal Monthly (Taipei, Taiwan). 2009; 225: 93-97 (in Chinese). 